\title{
(C) \\ HEALING OF A LARGE PERIAPICAL LESION AFTER CONVENTIONAL ROOT CANAL TREATMENT: A CASE REPORT
}

\begin{abstract}
The infected pulp, metabolic products, microorganism toxins, mechanical irritations, chemical agents, trauma, foreign substances, and host defense play a role in periapical tissue diseases. Options for the treatment of large periapical lesions vary from apical surgery and/or non-surgical root canal treatment to extraction. Although apical surgery may be a treatment option in these cases, conventional root canal treatment must be considered as the first alternative. In the present case report, we aimed to report that a surgical approach is not always required in case of a large size of a periapical lesion and healing occurs even in large periapical lesions after conservative endodontic therapy.
\end{abstract}

Keywords: Root canal therapy, periapical diseases, endodontic inflammations.

\author{
Datma Kaya ${ }^{1}$ \\ (D) * Kerem Engin Akpınar ${ }^{2}$ \\ (D) Recai Zan ${ }^{3}$ \\ (D) Demet Altunbaş ${ }^{3}$
}

1 Specialist in Endodontics. Kayseri Özel
Uzmandent Dental Hospital, Kayseri, Turkey
2 Khoja Akhmet Yassawi International
Kazakh -Turkish University, Faculty of
Dentistry, Turkestan, Kazakhstan.
${ }^{3}$ Sivas Cumhuriyet University, Faculty of
Dentistry, Department of Endodontics, Sivas,
Turkey.

Received : :03.03.2020

Accepted $\quad: 10.06 .2020$

How to Cite: Kaya F, Akpınar KE, Zan R, Altunbaş D. Healing of a Large Periapical Lesion After Conventional Root Canal Treatment: A Case Report. Cumhuriyet Dent J 


\section{INTRODUCTION}

Dental pulp infections are caused by deep caries, mistakes in the dental procedure, trauma, or a combination of these. ${ }^{1}$ Most of the periapical lesions of endodontic origin are caused by an inflammatory response in the periradicular tissues of teeth with nonvital pulps. It is caused by an imbalance between host defense and microbial factors. As a result of this, resorption of hard tissues, local inflammation, and destruction of other periapical tissues occur. ${ }^{2}$ One of the causes of dental pulp infection, traumatic injuries of teeth generally include the anterior teeth of young patients. The occurrence of pulpal necrosis and microbial infection will cause a periradicular lesion to develop. ${ }^{1}$ These periradicular lesions are usually diagnosed when a routine radiographic examination is performed and/or because of acute toothache. ${ }^{3}$ It is possible to categorize most of the periradicular lesions (>90\%) as dental granulomas, radicular cysts, or dental abscesses. ${ }^{4}$ Periradicular lesions cannot be diagnosed as cystic and noncystic lesions according to radiographic characteristics. ${ }^{2}$ In addition to radiography, histological examinations are needed for the diagnosis of lesions. ${ }^{5}$ Regardless of the size of a lesion, conservative treatments should be the first choice for the treatment of these lesions. ${ }^{6}$ In recent years, newer techniques, instruments, and materials have been improved with the increased awareness of the complexity of root canal systems. The abovementioned advancements have significantly improved the clinician's success rate. ${ }^{7}$ Generally, in the conservative treatment of periapical lesions, calcium hydroxide $\left(\mathrm{Ca}(\mathrm{OH})_{2}\right)$ therapy has been utilized for the stimulation of apexification, the repair of perforations, and the treatment of root fractures and inflammatory root resorptions. $\mathrm{Ca}(\mathrm{OH})_{2}$ has an accelerating effect on periapical tissue healing due to its high $\mathrm{pH}$, neutralization of the acidic products of osteoclasts, induction of cellular differentiation and mineralization. ${ }^{8}$ Researchers have reached the general consensus that successful results will be obtained by eliminating bacteria from the root canal system with efficient biomechanical preparation. ${ }^{9}$ However, when there is no response to treatment, persistent periradicular lesions may require surgical procedures such as apical resection and curettage. ${ }^{10}$

\section{CASE REPORT}

A 20-year-old male patient was referred to the Department of Endodontics at the Dental Faculty of Sivas Cumhuriyet University with the pus drainage in his maxillary right central-lateral incisors and canine tooth. Written informed consent was obtained form the patient who participated in this study. According to a dental anamnesis taken from the patient, the related teeth were traumatized in the past. Periapical radiography (Figure 1) showed the presence of a large lesion in periradicular tissues.

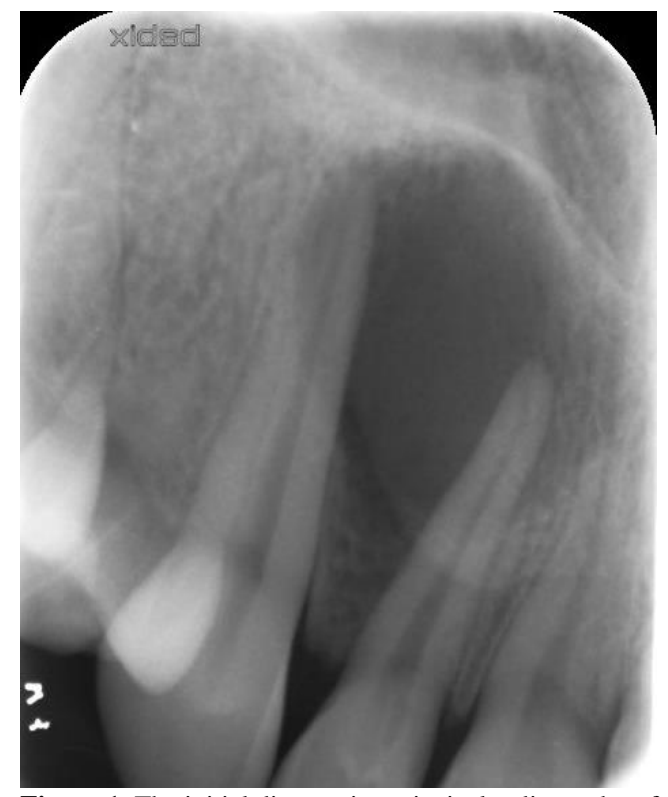

Figure 1. The initial diagnostic periapical radiography of the patient.

The intraoral examination showed that the palatinal cortical bone was perforated. Electronic pulp testing (Electric pulp tester, Parkell, Farmingdale, NY) was applied to the teeth related to the periapical lesion, and the test resulted in a negative response. After evaluating all the diagnostic data, root canal treatment for the teeth of the patient was planned. After local anesthesia, access cavities were prepared and a rubber dam was applied. Necrotic pulp tissues were extirpated, and the working lengths were identified using the electronic apex locator (Propex Pixi; Dentsply Maillefer, Ballaigues, Switzerland). The canals were biomechanically prepared by K-type and $\mathrm{H}$ type hand files using the step-back technique. While performing the instrumentation, the canal was irrigated using $2.5 \% \mathrm{NaOCl}$ (Imicryl Dental, 
Konya, Turkey) solution. The final irrigation was performed using $2.5 \% \mathrm{NaOCl}, 17 \%$ EDTA (Werax, Turkey), normal saline, and 2\% chlorhexidine (Werax, Turkey), respectively. Ca $(\mathrm{OH})_{2}$ medicament (Kalsin, Turkey) was applied to the root canals, and the access cavity was sealed using Cavit (3M ESPE, Neuss, Germany). There were no symptoms during the second visit, and the root canals were then obturated by employing the cold lateral condensation technique by utilizing AH Plus sealer (Dentsply, Germany) and gutta-percha (Figure 2a).

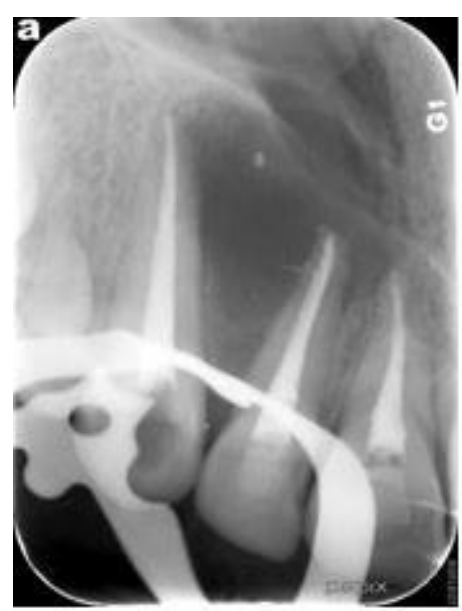

Figure 2. (a) Postoperative periapical radiograph

Composite resin was used for the restoration of the access cavity. Three months following the filling of the root canals, the patient was still asymptomatic, and a periapical radiograph showed the decreased size of the radiolucency and trabecular bone formation (Figure 2b).

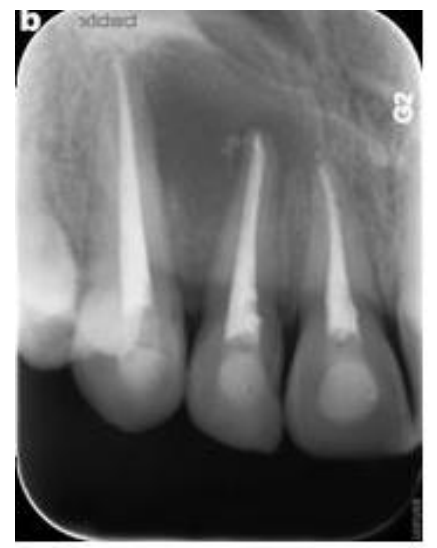

Figure 2. (b) 1 month review,

The patient was examined radiographically for three months (Figure 2c,2d,2e), and during the last control visit (15 months), the radiographic examination demonstrated that healing was continuing (Figure 2f).

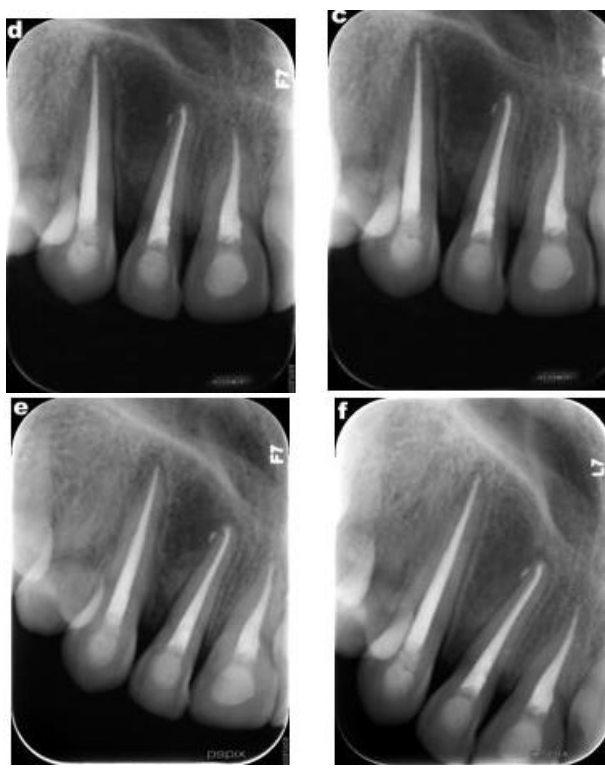

Figure 2.(c) 3 months review, (d) 6 months review, (e) 12 months review (f) 15 months review.

\section{DISCUSSION}

After trauma, some pulps remain normal, whereas others become necrotic. Necrotic pulp represents a nutritional supply for pathogenic bacteria, and after a series of reactions, lesions occur in the periradicular region. ${ }^{11}$ Although traditional imaging methods are often used for diagnosis and treatment planning in endodontics, advances in imaging technology contribute greatly to the practice of endodontics. Cone-beam computed tomography (CBCT), which were first used in dentistry in 1997 and enable three-dimensional imaging, assist the clinician at every stage of endodontic treatment. ${ }^{12}$ In 2011, an attitude statement was published on the use of CBCT in endodontics by the American Endodontics Association (AAE) and the American Academy of Oral and Maxillofacial Radiology (AAOMR). According to the statement CBCT should not be routinely performed in every patient, it should be analysis carefully in cases where traditional diagnostic methods are inadequate. ${ }^{13}$ In accordance with the statement, we made our diagnosis and treatment planning with conventional radiographs, because CBCT exposed the patient to extra ionizing radiation. We decided to apply additional diagnostic methods (cbct imaging, aspiration biopsy, etc.) and surgical procedures in case of suspected cystic lesions if we do not respond to our treatment during the follow-up period. There is a disagreement about the treatment method in large 
periradicular lesions. ${ }^{14}$ Matsumoto et al. ${ }^{15}$ showed that the prognosis for the treatment of large periradicular lesions was worse in comparison with small lesions. On the other hand, Strindberg ${ }^{16}$ and Sjogren et $a .^{17}$ determined no significant differences in the healing frequency between lesions that were initially larger than $5 \mathrm{~mm}$ and lesions that were smaller than $5 \mathrm{~mm}$. Long-term observation is important after the treatment of these lesions. Furthermore, in many studies, apical lesions with a size of up to $20 \mathrm{~mm}$ have been reported to improve after conventional root canal treatment. ${ }^{12}$ In a long-term clinical study, 42 teeth with large cyst-like lesions were treated by conventional root canal treatment, and $73.8 \%$ of all cases were reported to heal completely after nonsurgical treatment. ${ }^{18}$ There are also disadvantages such as reducing bone support, destroying the inner blood vessels and nerves that feed the teeth adjacent to the surgical site, damaging the mental foramen, lower alveolar nerve branch and/or anatomical structures such as artery, nasal cavity, maxillary sinus, the formation of anatomical defects, postoperative pain, and the inability to apply surgery to pediatric patients in the surgical treatment of cystic lesions in terms of cooperation. ${ }^{19}$ We preferred the traditional root canal treatment considering these case studies and disadvantages of surgical treatment. Also with the development of technology, regenerative treatment methods have been developed as an alternative to classical treatment methods. The aim of these methods is to replace damaged cells in the root canal system with a new one and reconstruct pulp vitality. ${ }^{20}$ There are some disadvantages clinical and biological complications such as color change in the crown, development of resistant bacterial strains and allergic reactions can be observed. In addition, if necrosis has developed completely in the pulp tissue, revascularization may not be possible. ${ }^{21}$ Whether the root canal obliteration and / or apical periodontitis will develop in the long term has not been exactly established. ${ }^{22}$ Most of the studies in the literature are limited with animal experiments, in vitro studies and case reports of studies on humans. ${ }^{20}$ Therefore, more clinical trials with long-term follow-up are needed to eliminate existing disadvantages. ${ }^{23}$ Considering these disadvantages, we did not prefer regenerative endodontic treatment in our case. We wanted to emphasize once again that the routine treatments used in endodontics may also improve in large infections and show that it can be successful when traditional treatment is performed in the appropriate protocol without requiring an additional procedure. Conventional root canal treatment is based mainly on removing a microbial infection from the root canal system. Irrigation agents used during the biomechanical preparation help reduce the microbial flora of the infected root canals. ${ }^{24}$ Furthermore, $\mathrm{Ca}(\mathrm{OH}) 2$ treatment for a certain period before the endodontic treatment of large periapical lesions is complete has a positive effect on the disappearance of symptoms and the control of periradicular infection. ${ }^{25} \mathrm{Ca}(\mathrm{OH}) 2$ makes a contribution to the healing of periradicular lesions through an anti-inflammatory effect, neutralization of acid products, alkaline phosphatase activation and antibacterial effect. ${ }^{26}$ We preferred $\mathrm{Ca}(\mathrm{OH}) 2$ treatment before the endodontic treatment of large periapical lesions was complete in our study and completed our treatment when the related teeth became asymptomatic. In the radiographic examination, density change within the lesion, trabecular reformation, and lamina dura formation, and in the clinical examination, asymptomatic teeth and healthy soft tissue7 show us that the treatment has been successful during periodic check-up visits.

\section{ACKNOWLEDGEMENTS}

None

\section{CONFLICTS OF INTEREST STATEMENT}

The authors declare no conflicts of interest.

\section{Geniş Periapikal Lezyonların Geleneksel Kök Kanal Tedavisini Takiben İyileşmesi: Vaka Raporu $\ddot{O} Z$}

Periapikal dokularda lezyon gelişmesinde enfekte pulpa, mikroorganizmalarn toksinleri, metabolik ürünler, kimyasal ajanlar, mekanik irritasyonlar, yabancl maddeler, travma ve konak savunmast rol oynamaktadır. Büyük periapikal lezyonların tedavisi için seçenekler, cerrahi olmayan kök kanal tedavisi ve/veya apikal cerrahiden çekime kadar değiş̧mektedir. Bu olgularda apikal cerrahi bir tedavi seçeneği olabilse de konvansiyonel kök kanal tedavisi ilk tercih olmalıdrr. 
Bu olgu sunumunun amacl, geniş apikal lezyonların her zaman cerrahi tedaviye ihtiyaç olmaksızın konservatif bir endodontik tedaviyi takiben iyileştiğini göstermektir.

Anahtar Kelimeler: kök kanal tedavisi, periapikal hastalıklar, endodontik inflamasyon.

\section{REFERENCES}

1. Sundqvist G. Taxonomy, ecology, and pathogenicity of the root canal flora. Oral Surg Oral Med Oral Pathol 1994;78:522-530.

2. Nair PR. Apical periodontitis: a dynamic encounter between root canal infection and host response. Periodontol 2000 1997;13:121-148.

3. Yılmaz B, Şengül E, Özkurt FE, Gül A, Akdağ M. Cilde fistülize bir radiküler kist olgusu. ENTcase 2016;2:109-113.

4. Morotomi T, Washio A, Kitamura C. Current and future options for dental pulp therapy. Japanese Dent Sci 2019;55:5-11.

5. Önay EO, Üngör M, Gülşahı K. Kist benzeri geniş periapikal lezyonlu dişin endodontik tedavisi: vaka raporu. ADO J Clin Sci 2008;2:131.

6. Gupta A, Duhan J, Hans S, Goyal V, Bala S. Non surgical management of large periapical lesions of endodontic origin: a case series. J Oral Hlth Comm Dent 2014;8:172-175.

7. Saatchi M. Healing of large periapical lesion: A nonsurgical endodontic treatment approach. Aust Endod J 2007;33:136-140.

8. Foreman P, Barnes I. A review of calcium hydroxide. Int Endod J 1990;23:283-297.

9. Gündoğar M. Impact of intracanal calcium hydroxide or triple antibiotic paste on bond strength of root canal sealers: an in vitro study. Cumhuriyet Dent J 2016;19:229-237.

10. Hoen MM, LaBounty GL, Strittmatter EJ. Conservative treatment of persistent periradicular lesions using aspiration and irrigation. $\mathbf{J}$ Endod 1990;16:182-186.

11. Ceyhan D, Akdik C. Apeksifikasyondan apeksogenezise geleneksel ve güncel tedavi yöntemleri. EÜ Dişhek Fak Derg 2018;39:8-18
12. Yıldırım C, Akgün ÖM, Polat GG. Periapikal lezyonlu genç daimi dişlerde pulpa dentin kompleksinin yenilenmesi. J Dent Fac Atatürk Uni 2013;23:269-273.

13. Akyıldız BM, Sönmez I. Rejeneratif endodontik tedavi: bir literatür derlemesi. Turkiye Klinikleri J Ped Dent-Special Topics 2016;2:1-12.

14. Mirković S, Tadić A, Đurđević-Mirković T, Levakov A. Comparative analysis of accuracy of diagnosis of chronic periapical lesions made by clinical and histopatological examination. Med Pregl 2012;65:277-280.

15. Matsumoto T, Nagai T, Ida K, Ito M, Kawai Y, Horiba N, Sato R, Nakamura H. Factors affecting successful prognosis of root canal treatment. J Endod 1987;13:239-242.

16. Strindberg LZ. The dependence of the results of pulp therapy on certain factors-an analytical study based on radiographic and clinical follow-up examination. Acta Odontol Scand 1956;14:1-175.

17. Sjögren U, Hägglund B, Sundqvist G, Wing K. Factors affecting the long-term results of endodontic treatment. J Endod 1990;16:498-504.

18. Çalışkan M. Prognosis of large cyst-like periapical lesions following nonsurgical root canal treatment: a clinical review. Int Endod J 2004;37:408-416.

19. Kanmaz F, Altunbaş D, Zan R, Akpınar KE. Nonsurgical endodontic treatment of a large periradicular lesion. Turk Endod J 2017;2:21-24.

20. Nale T, Demiriz L, Bodrumlu EH. Travmaya uğramış immatür maksiler daimi ön kesici dişin pulpa revaskülarizasyonu: bir olgu raporu. J Int Dent Sci 2016;1:60-64.

21. Özbay Y, Erdemir A. Endodontide konik 1şınlı bilgisayarlı tomografinin kullanımı. Kırıkkale Univ Tıp Fak Derg 2016;18:139-150.

22. Ertaş E, Arslan H, Çapar İ, Gök T, Ertaş H. Endodontide konik 1şınlı bilgisayarlı tomografi. J Dent Fac Atatürk Uni 2014;24:113-118.

23. Ball RL, Barbizam JV, Cohenca N. Intraoperative endodontic applications of cone-beam computed tomography. J Endod 2013;39:548-557.

24. Pereira TC, Vasconcelos LRdSM, Graeff MSZ, Ribeiro MCM, Duarte MAH, de Andrade FB. 
Intratubular decontamination ability and physicochemical properties of calcium hydroxide pastes. Clin Oral Investig 2019;23:1253-1262.

25. Paredes-Vieyra J, Enriquez FJJ. Success rate of single-versus two-visit root canal treatment of teeth with apical periodontitis: a randomized controlled trial. J Endod 2012;38:1164-1169.
26. Eren SK, Özyürek EU. Influence of cavity design on calcium hydroxide removal from root canal irregularities. Cumhuriyet Dent J 2019;22:419-425. 